\title{
Russian liberal historiography and European philosophical thought in the late 19th century and early 20th century: Man in the space of culture
}

\author{
Tatyana Ivanovna Sidnenko - Primoz Repar - Sergey A. Polevoy - Elena V. \\ Shamalova - Nina I. Kryukova
}

DOI: 10.18355/XL.2020.13.03.17

\begin{abstract}
The article considers the ideological and theoretical legacy of liberal historians of the late XIX - XX centuries in the context of the study of the main philosophical trends of this period. The purpose of the article is to highlight the current ideas about the influence of positivism, neo-Kantianism and Marxism on Russian liberal historiography, and to identify the main trends in the history of studying the problem. Based on the comparison of the experience of reforming the historical science of the last century with modern requirements and principles of development, the analysis of the main trends in the formation of innovative projects by P. G. Vinogradov, N. I. Kareev, A. S. Lappo-Danilevsky, P. N. Milyukov, I. M. Grevs, D. M. Petrushevsky is presented. Of particular relevance is the appeal to the discussions of St. Petersburg historians, whose scientific and pedagogical activities in the field of conceptual and methodological updating of historical science in Russia had a global character. The so-called cognitive model of knowledge development in society in critical epochs, which has found its embodiment in the pedagogical practice of scientists, is still relevant today.
\end{abstract}

Key words: European philosophical thought, Russia, liberal historiography, human personality

\section{Introduction}

At the turn of the 19-20th centuries, there was a global revision of the methodological and philosophical foundations of the development of the humanities. The formation of a new vision of the tasks of historical science and ideas about the nature and specifics of the methodological practice of the historian was accompanied by active polemics. Almost all historians, Russian and foreign, were involved in it. Assessing the depth of historiosophical and sociological discussions about Man in the cultural space, it is necessary to bring to the fore such problems as the personality of a scientist in the system of scientific knowledge, the personality of a person in society, the legal boundaries of world perception, the ability of a person to understand the world, the boundaries of scientific knowledge. In the historical and philosophical literature, there is no unified position on the question of the time of perception of positivist and neoKantian ideas by the largest Russian representatives of liberal historiography: A. S. Lappo-Danilevsky, N. I. Kareev, M. M. Kovalevsky, D. M. Petrushevsky, P. N. Milyukov, V. M. Khvostov, M. M. Khvostov.

The social reality of the era of globalization has put the humanities before the need for a systematic understanding of the ways of humanitarian knowledge. From the methodological opposition of the natural sciences and the spiritual Sciences (as using fundamentally different cognitive strategies), scientists gradually come to realize the unity of the principles of scientific knowledge about the natural Sciences, about life and about man (Ramazanov, 1999). These ideas, developed by liberal scientists of the late 19-20th centuries, also encourage modern researchers to think more deeply about the problem of "methodological crisis of science at the turn of the century" (Korzun, 2000), "man in the space of culture". Today, at the epicenter of modern reflections of the scientific community - the integrity and consistency of the historical process, its systemic qualities as part of the world whole, the prospects and possibilities of 
historical knowledge. A comprehensive analysis of modern Russian and foreign literature has revealed serious discrepancies in the assessment of historiosophical positions and methodological orientation of Russian liberal historians in the context of comparing their positions with positivist and neo-Kantian trends (Malinov, 2003).

The historical-social and political-legal positions of liberal historians were largely determined by the nature of methodological research, reflecting the ideas about the nature, driving forces of historical development and the specifics of historical knowledge (Sidnenko, 2006). In this regard, liberal historians were primarily interested in positivism, neo-Kantianism, and Marxism. Forming its attitude to them, Russian liberal historiography developed its own methodological positions (Sidnenko, 2008: 55).

\section{Russian scientific thought}

The traditional dispute in Russian scientific thought about the degree of influence of certain European scientific schools and philosophical trends on the formation of historical thought in Russia at the turn of the 19-20th centuries remains relevant for modern researchers of the work of liberal historians. The key parameters for the assessment and objectivity of judgments are, on the one hand, the theoretical and methodological basis underlying the epistemological and ontological constructions of scientists, on the other hand, their political and legal views on the prospects for the development of society and man in it, in the conditions of revolutionary upheavals in Russia. Thus, based on the specifics of the methodology of neo-Kantianism, it is wrong to classify N. I. Kareev as a neo-Kantian, based only on the identification of his "ethical attitude" to history with the neo-Kantian method of attribution to value. First, by" ethical attitude " N. I. Kareev meant not the method of selecting the essential in history, but only the ethical assessment of the past, the necessity and inevitability of which, unlike the founders of the Baden school, he recognized (Kareev, 1913: 278, 283). Secondly, the "ethical attitude" only complemented the unified General scientific method of cognition, Which N. I. Kareev called the "theoretical" attitude (Kareev, 1913: 278). It is obvious that the theoretical basis underlying the conclusions of N. I. Kareev, which he used as arguments to explain the uniqueness of the historical method of knowledge, is fully justified by the means of positivism. Moreover, in the General system of scientific views of the scientist, there is no mention of the subjectivity of the historical method of knowledge, only the subjectivity of the scientist's attitude to the historical facts established by scientific research is emphasized (Dzhivelegov - Kareev, 1913: 326).

On the contrary, V. M. Khvostov's views should be recognized as neo-Kantian in their basis (Khvostov, 1919). It was V. M. Khvostov who developed neo-Kantian ideas most fully and deeply in pre-revolutionary Russia. Moreover, socio-political events in Russia in 1905-1918 dramatically influenced the final transition of the historian to the position of neo-Kantianism.

Studying historical patterns, the influence of socio-political and socio-legal processes on the change of the scientific paradigm in history, on the emergence of new scientific trends and ideological concepts in society, in contrast to the positivists, N. I. Kareev, M. M. Kovalevsky, A. S. Lappo-Danilevsky, P. N. Milyukov admitted the possibility of catastrophes in history, a combination of progress and decline in the evolution of society (Kareev, 1915: 155, 158; Kovalevsky, 1913: 1, Lappo-Danilevsky, 1923: 6-7; Milyukov, 1903: 11; Milyukov, 1890: 1). It should be emphasized that liberal historians do not borrow the scheme of $\mathrm{O}$. Conte, and the application of his scientific direction in the framework of historical research. This position was expressed in the relationship of understanding the driving forces of social development with the solution of the problem of progress in history. Sharply criticizing the metaphysical attempts to explain the nature of phenomena is not based on empirical data and using

XLinguae, Volume 13 Issue 3, June 2020, ISSN 1337-8384, ISSN 2453-711X 
theory constructions, P. N. Miliukov, at the same time took the existence of issues not addressed by experience, but only available to "philosophical explanation" (Milyukov, 1918, Part 2, 3]. P. N. Milyukov tried to prove that his theoretical and conceptual constructions are strictly "positive" in nature, completely based on facts. But in fact, no scientist can completely eliminate subjectivism in their research. This is evidenced by the chosen logic of the scientist's evidence in the issue of identifying patterns in history. P. N. Milyukov gave the following proofs of his position: "... the Wide application of the idea of regularity necessarily follows from the modern view of the world, just as the idea of expediency followed from the old worldview. We accept the regularity of historical phenomena completely regardless of whether history can reveal these desired laws to us" (Milyukov, chapters 1,8). This view is a clear reflection of the influence of neocantianism on P. N. Millyukov, but it did not take place to the extent that allows us to talk about the neocantian methodology of research. The scientist was true to the position that in the process of research, objective fact is primary, and only on its basis is a theory or concept created. Unlike the neo-Kantians, he insisted that history, like the natural Sciences, had its own laws, and the historian could not limit himself to describing individual facts, but should strive for generalizations. Moreover, P. N. Milyukov raised the question of the need to distinguish between a fact and representations about it (Kareev, 1883: 173).

The impact of neo-Kantianism on the Russian historiography of the XIX century was more pronounced in the sphere of methodology. Within the framework of the neoKantian current, a radical break was made in the ideas about the nature and form of historical knowledge, on which Russian historical science was based (Sidnenko, 2019: 26, 29). The establishment of the leading positions of neo-Kantianism in Russian historiography of the early twentieth century was facilitated by the desire of the neoKantians to combine methodological constructions with the system of historical knowledge, to turn the methodology of history into a special scientific discipline. Fundamentally diverging from positivism in the interpretation of the final orientation of the knowledge of history, the methodology of neo-Kantianism absolutized the practice of concrete historical research based on factographism, which the positivists considered as a preparatory stage of the development of historical knowledge (Sidnenko, 2008: 55).

At the present level of scientific research of the process of interpenetration of methodological and conceptual structures in the philosophical and historical European thought in a comparative analysis with the Russian historiographic research practice, we will highlight the main trends that influenced the spread of neo-Kantianism as a philosophical and methodological direction. First, the statement and theoretical constructions concerning the role of the individual in history and science. Social and political upheavals of the early twentieth century. they led the theorists of Russian liberal-historical thought to the need for a value reorientation in the justification of historical and political events, the possibility of establishing a "legal state" (Kareev, 1876: 54-56) in Russia.

Developing a comparative analysis of existing value judgments in science regarding the diversity of research approaches to the role of the individual in history, we emphasize the diversity of existing trends in Russian socio-political and historicalsociological thought of that time. As part of the study of the specifics of the approaches of liberal historians, we will highlight some of the most characteristic positions. For example, P. N. Milyukov took the position of Marxists in determining the natural course of history. The scientist refuted any attempts to evaluate the creativity of the individual, the free expression of human thought, as opposed to the laws of the historical process. All creative activity, including scientific activity, of the individual, was considered by him exclusively within the framework of the laws that govern the development of society, culture, and society. In this regard, constant opponents of p. N. Milyukov were P. B. Struve and N. I. Kareev. If P. B. Struve 
questioned the scientific nature of $\mathrm{p}$. N. Milyukov's attempts to explain the role of the individual in history using the idea of regularity, then N. I. Kareev emphasized a significant element of subjectivity in the activity of the individual, which not only affects its personal fate, but also affects social phenomena, becoming one of the main factors of progress (Kareev, 1876: 114-115, 142). Moreover, without identifying a logical mechanism for the influence of psychological regularity on the behavior of individuals in P. N. Milyukov, P. B. Struve rejected the idea itself.

It is obvious that the differences in the approaches and positions of N. I. Kareev and P. N. Milyukov to the scientific substantiation of the specifics of the role of the individual in history consisted in their interpretation of the factors of the historical process. P. N. Milyukov put forward a sociological regularity in the first place, believing that "personality" is present in history as an element of "chance" (Milyukov, 1993: Parts 1, 14). N. I. Kareev's dominant position is that the individual is given a more significant role. On the other hand, P. N. Milyukov distinguished the spheres of perception of this problem: practical and theoretical, and accordingly identified two approaches to solving the problem. In public activity, P. N. Milyukov recognized a more active role for the individual.

Despite the similarity with extending the period of the Marxist interpretation of Man's place in the world of personality in history, a scholar in the Sciences, the position P. N. Milyukov, in contrast to the Marxist concept of "the decisive role of the masses in history", did not record quantitative growth of the consciousness of the masses in the studied social phenomena and focused on the possibility of qualitative changes (Milyukov, 1993: 1,18). Thus, Milyukov clearly shows historical optimism as an integral feature of his scientific and social activities, in contrast to Milyukov. Kareev, who is inclined to see in the activities of individuals more elements of irrational than conscious creativity.

Seeing in the person "the only factor of history" N. I. Kareev sought to find the laws of social development in the properties of human nature. Adherents of social biologism were, in particular, I. V. Luchitsky (1868), P. G. Vinogradov (1905), M. M. Kovalevsky (1905). The desire to find in psychological laws the key to understanding the social process, reducing the variety of trends in historical development to human nature as their primary source, an attempt to combine psychological and economic points of view in the interpretation of the history of society reflected one of the trends in the development of liberal historiography at the end of the 19th century (Sidnenko, 2014: 1491).

At the same time, biopsychologism in the explanation of history has become one of the weakest sides of the methodological views of liberal historians, leading to historical agnosticism, distracting historians from the study of historical regularities in their concrete historical works. The fascination with the biopsychological explanation of history contradicted the desire of liberal historiography to reveal the significance of socio-economic relations in the social process. In the last quarter of the 19th century not idealism, which proclaimed the idea as the Creator of history, but biopsychologism, as a more refined form of idealistic worldview, becomes the main opponent of the materialistic understanding of history (Sidnenko, 2019: 29). Note, however, that pointing to historical idealism as the essential content of liberal historiography is clearly not enough. In fact, the term "historical idealism" is extremely ambiguous. Moreover, the methodological views of liberal historians who were influenced by a materialistic understanding of history were too complex and contradictory to be reduced to a purely idealistic system. The defining feature of the methodological ideas of liberal historians is a certain eclecticism, which is expressed in a mixture of materialistic and idealistic ideas about the nature and driving forces of the historical process in the presence of a common idealistic worldview (Sidnenko, 2019: 30). It is important to emphasize that the influence of biopsychologism affected 
mainly in the sphere of their theoretical views about the nature of Man, about the place of Man in the space of culture, in concrete historical works, on the contrary, the object of research is usually socio-economic relations in a given period of time.

Secondly, an important result of the author's research is the fact that the positions of liberal historians were differentiated within the scientific direction, which refutes the widespread view of the unity of the liberal direction of Russian historiography. The positions of liberal historians in their critical attitude to neo-Kantianism as a philosophical direction were quite different (Sidnenko, 2014). To a large extent the desire to revise a number of provisions of the Baden school stemmed not only from the originality of the previous development of Russian historical and philosophical thought, but also the specifics of the socio-political situation in Russia from 1903 to 1918 years, the visible contradictions of neokantianism doctrine, the inconsistency of some of his methodological principles, the practice of concrete historical research. In contrast to neo-Kantianism, the research practice of liberal historiography reached a high scientific level by the end of the 19th century, mainly associated with success in the study of socio-economic history. Liberal historians gave priority to history, philosophy, and sociology in the General system of Sciences and, as a result, to the system of Humanities education. The basis for this position is the use of special historical and philosophical methods of knowledge, including the way of understanding the past of humanity in the system of scientific values (LappoDanilevsky, 1910) For example, P. Rickert contrasted history and philosophy, and A. S. Lappo-Danilevsky pointed out that it was permissible for a historian to justify values, although he considered it a matter of philosophical science. In fact, the doctrine of value itself was considered by A. S. Lappo-Danilevsky to be one of the sociological problems (Lappo-Danilevsky, 1923). So, A. S. Lappo-Danilevsky, following the neo-Kantian tradition, fundamentally objects to the monistic approach, solving questions about the method and subject of history from dualistic positions. A. S. Lappo-Danilevsky developed a methodology, not his own philosophy of history, which was his main divergence from neo-Kantianism. Neokantians philosophical beliefs manifested in A. S. Lappo-Danilevsky in his division of Sciences into nomothetical and idiograficescoe. The peculiarity of the position of A. S. LappoDanilevsky is that in contrast to the neo-Kantians of the XIXth century, who attributed all natural Sciences to nomothetic, and sociology to idiographic, he attributed sociology to nomotetic Sciences, and the history of nature to idiographic (Lappo-Danilevsky, 1902: 25).

Third, considering the specifics of historical knowledge and the epistemological roots of historical knowledge, liberal historians turned to the problem of building a cognitive model of man at the turn of the century. In the General process of modernizing scientific research at the turn of the century, a special place was taken by the recognition of the cultural value of information, which not only changes the cognitive model of a person, i.e. his ability to mentally perceive and process external information, but also the idea of the educational system as a whole. Research by the author of liberal-historical thought of the late XIX - early XX centuries. in the context of historical and comparative comparison of the program provisions of the heritage of the Russian liberal historiography with modern projects of transformation of the education system, the following conclusions can be drawn.

The problem of comparative analysis of educational systems of Russian and Western civilizations was first raised in Russian history by representatives of liberal historiography. Scientists have identified the discrete, fragmented non-system nature of this process, having considered in some detail the issue of translating knowledge and ideas in Russian society. The study focused not only on the problem of the variability of ideological borrowing in different epochs, but also on focusing on specific cognitive models of knowledge development in society in critical epochs. The theoretical model has also been implemented in practice (Sidnenko, 2015: 156). 
The growth of socio-political and cultural-legal contradictions in Russia at the turn of the 19-20th centuries gave rise to serious doubts among some historians about the possibility of rational justification of generally significant values and processes. The increase in the scale of criticism of the methodology of neo-Kantianism by Russian socio-philosophical thought also influenced the strengthening of methodological disputes among historians. Attempts of liberal historians to establish the relationship between the socio-political development of society and changes in the economic system (M. M. Kovalevsky, N. I. Kareev, I. V. luchitsky, P. G. Vinogradov, P. N. Milyukov, D. M. Petrushevsky), cannot be understood outside of the radical shifts in all spheres of life that Europe and Russia experienced at the end of the 19th century. in close connection with the ideas of liberal historiography about the revolution, its regularities in the historical process, and the attitude of its representatives to the Marxist interpretation of the revolutionary process in history. And finally, the development of historical science was for advancing the historiographical and specific historical studies to identify the driving forces of history and progress in historical science, the nature of social relations in a certain historical epoch, understanding the specifics of social consciousness. Changes in research guidelines in historical science were mainly due to the search for strict scientific knowledge, the desire to identify the relationships of historical events, to identify the special place of Man in the space of culture. This new paradigm of research has most fully manifested itself in the work of liberal historians.

It is no exaggeration to say that the concept of feudalism (P. G. Vinogradov, M. M. Kovalevsky, N. I. Kareev, I. V. luchitsky, P. N. Milyukov, D. M. Petrushevsky) in Russian historiography was formed under a certain ideological influence of the materialist theory of the historical process. This influence affected not so much the assessment of individual historical facts and processes, but rather the General theoretical principles that guided scientists in their research of specific problems in the history of Western Europe and Russia. So, I. M. Greaves explained the interest in the knowledge of "economic history" by the achievements of political economy and statistics; the relevance of social issues in modern social life; the internal development of historical science and the influence of Marxism (Grevs, 1899: 34-35).

\section{Opposing influences}

But it is also worth noting opposing influences, at least indirect ones, that at the end of the 19th century and in the early twentieth century formed Russian thought. They formed in opposition to Russian liberal historiography and dominated its European counter-current. Here, of course, we cannot get past the new mentality, actualized through the writings works of Dostoyevsky. It created something that the philosopher Nikolai Berdjaev calls the Russian idea. (Berdyaev, 1979)

From Dostoyevsky onwards, Berdjaev included, we differentiate people by whether they read Dostoyevsky or not. His thought is deeply Russian and existential at the same time. It is no coincidence that the Soren Kierkegaard was composing his own manifesto of the Single Individual, (Kierkegaard, 1998; Martin et al., 2020) known by the title Works of Love (Kierkegaard 1995) while Marx and Engels were writing the Communist Manifesto Kierkegaard's thought began to appear in journals with first fragmented translations in Russia as early as the end of the 19th century. Thinkers such as Nikolai Berdjaev and later Lev Shestov include both Dostoevsky and Kierkegaard in new personalistic philosophy that became quite influential after First World War. They both share a common anti-ecclesiastical position (for example at Dostoyevsky in the Grand Inquisitor), the subjectivity of truth, the freedom of a believing individual, and a sharp critique of the existing European positivist spirit, which is also prevalent in governing European institutions at that time. There are also surprising things: the kinship of Kierkegaard's notion of the term Salighed, (Khan,

XLinguae, Volume 13 Issue 3, June 2020, ISSN 1337-8384, ISSN 2453-711X 
1982) which, though derived from the Protestant tradition, has much in common with the Russian notion of "Foolishness for Christ", which is also at work in key heroes of Dostoyevsky's novels from Knez Mishkin in the novel Idiot, Sonja in Crime and Punishment, to Alyosha and Zosyma in the Karamazov Brothers. That influence continued in the development of Russian scientific and pedagogical activities until the First World War. (Porubsky, 2017; Porubsky, 2018). Accordingly, Russian existential thought was spread to Europe through those exiled, especially in Paris.

\section{Conclusion}

We note that the anthropological turn in socio-humanitarian research of the turn of the 19th and early twentieth centuries radically predetermined the further development of Russian liberal historiography. Highlighting the influence of positivism, neoKantianism, and Marxism on the liberal historiography of the late 19th and early twentieth centuries, we once again focus on the methodological independence of liberal historiography. The differentiation of the ideological and methodological positions of Russian historians was due to the originality of the previous development of Russian and foreign historical and philosophical thought, the specifics of the sociopolitical situation in Russia in 1905-1918 years, the understanding of the place and role of the individual in history, the Person in the space of culture. The study of sociopolitical and state-legal issues by liberal historiography reflected the needs of the historical consciousness of society and the development of science as a whole.

Using the example of scientific research by liberal historians presented in this article, we have illustrated the processes that reflected the dynamics of historiography at the turn of the century. At the beginning of the twentieth century, the range of problems covered, sources used and methods of their processing by historians expanded, which inevitably led to the evolution of both positivist and neo-Kantian ideas. The departure from classical methods in the works of liberal historians has put Russian science on a new stage of development in General theoretical, concrete historical and cultural terms (Sidnenko, 2014).

The desire of liberal historiography by applying a set of approaches to the study of historical and social laws reflected the general processes of the evolution of historical science in the early twentieth century. Namely, the analysis of the relationship of socio-economic relations and personality in history; culture, science, politics and ideology; the relationship of the socio-legal status of historical science, the personality of the historian in society with his specific historical and theoretical and methodological works, proposed by M. M. Kovalevsky, N. I. Kareev, A. S. LappoDanilevsky, P. N. Milyukov, D. M. Petrushevsky, allows us to make a statement about the high scientific significance and modernity of the conclusions of scientists. The legacy of liberal historians of the turn of the 19-20th centuries is also of particular significance in the framework of modern trends in the study of the typology of historical situations, the study of the role of the subjective factor in them, the interaction of different types of situations as stages in the development of the system that characterize its state.

The repeatability of systems of phenomena and processes, as well as the repeatability of situations, marks a return on a new level to the historical tasks that once faced humanity. And at the present time, in the period of re-evaluation of historical, cultural, social and legal values, the need to use the views of liberal historians in the development of the problem of" socio-psychological and state-legal conflicts in history, in society in a certain historical period " seems very relevant.

\section{Bibliographic references}

BERDYAEV, N. 1979. The Russian Idea. Praeger. Westnord. ISBN 0313209685.

DZHIVELEGOV A. K. - KAREEV, N. I. 2013. (To the 40th anniversary of scientific activity). In: Voice of the past, vol. 12, pp. 309-334. 
GREVS, I. M. 1899. Очерки из истории римского землевладения. (Преимущественно во время империи). Т. І. СПб.: Тип. М.М. Стасюлевича. 1899. XXIII.

KAREEV, N. I. 1913. Теория исторического знания. СПб. (Theory of Historical knowledge). СПб.: Тип. М.М. Стасюлевича.

KAREEV, N. I. 1915. Историология: (Теория исторического процесса). Пг., 1915. Historiology: (Theory of historical process).

KAREEV, N. I. 1883. Основные вопросы философии истории: критика историософских идей и опыт научных теорий исторического процесса (Main questions of philosophy of history). M. 1883. T. I.; T. II.

KAREEV, N. I. 1876. Философия истории и теория прогресса. Знание. № 2. (History of philosophy and theory of progress). Knowledge, vol. 2. pp. 27-36.

KHAN, A. 1982. Salighed in Kierkegaard's religious works. In: Studia Theologica Nordic Journal of Theology, vol. 36, n. 1, pp. 47-62. ISSN 0039-338X. doi: $10.1080 / 00393388208600008$.

KHVOSTOV, V. M. 1919. Theory of historical process: essays on philosophy and methodology of history. Moscow: Moscow scientific publishing house named after G. M. Mark at the Moscow scientific Institute.

KORZUN, V. P. 2000. Images of historical science at the turn of the XIX-XX centuries (Analysis of domestic historiographic concepts). Omsk, Ekaterinburg, Omsk. state University; Uralsk Publishing house. UN-TA, ISBN 5-7525-0808-8.

KOVALEVSKY, M. 1913. Социология на Западе и в России. Сб. Новые идеи в социологии. Вып. I. (Sociology in the West and in Russia). Edited by M. M. Kovalevsky and E. V. de Roberti. Collection of New ideas in sociology. Saint Petersburg: Education Publishing house, pp. 1-10.

KOVALEVSKY, M. M. 1905. Modern sociologists. SPb. Saint Petersburg: Publishing house. M. Merkushina. SB. New ideas in sociology). Vol. I.

KIERKEGAARD, S. 1998. The Point of View. Supplememt. The Single Individual. Princeton University Press. Princeton, New Jersey, pp. 99-144. ISBN 978-0-69114080-3.

KIERKEGAARD, S. 1995. Works of Love. Princeton University Press. Princeton, New Jersey. ISBN 0-691-05916-0.

LAPPO-DANIELEVSKY, A. S. 1923. Методология истории. Вып. II. Пг.,(Methodology of history. Vol. II.). Posthumous ed. - Petrograd: B. I.

LAPPO-DANILEVSKY, A. S. 1910. History of methodology. Vol. 1. SPb. СанктПетербург : Студ. изд. ком. при Ист.-филол. Фак).

LAPPO-DANILEVSKY, A. S. 1902. Basic principles of O. Comte's sociological doctrine. Problems of idealism. Moskva: Publishing House. I.N. Kushnerev and $\mathrm{K}^{\circ}$.

LUCHITSKY I. V. 1868. Адам Фергюсон и его историческая теория. Университетские известия. Киев, vol. 11. (Adam Ferguson and his historical theory), pp. 1-27.

MAHRIK, T. - VASBIEVA, D. - KRALIK, R - KONDRLA, P. 2020. Salvation as the teleological vector in Kierkegaard's practice in Christianity, In: European Journal of Science and Theology, vol.16, n. .4, pp.43-52. ISSN 1841-0464.

MALINOV, A. V. (Ed.) 2003. Historical science and methodology of history in Russia of the XX century: To the 140th anniversary of the birth of academician A. S. Lappo-Danilevsky. Saint Petersburg readings on the theory, methodology, and philosophy of history. Issue I. Severnaya Zvezda Publishing House. ISBN 5-901-95409-X.

MARTIN, J. G. - ROJAS, A. M. - KRALIK, R. 2020. The problem of the 'individual' concept in the Kierkegaard's journals. In European Journal of Science and Theology, vol. 16, n. 2, pp. 39-46. ISSN 1841-0464.

XLinguae, Volume 13 Issue 3, June 2020, ISSN 1337-8384, ISSN 2453-711X 
MILYUKOV, P. N. 1896-1903. Очерки по истории русской культуры. 1-е изд. СПб. 1896 - 1903. Ч. 1 - 2. (Essays on the history of Russian culture). 1st ed. SPb. $1896-1903)$.

MILYUKOV, Р. N. 1891. Рец. на: Историческое обозрение. Т. 1., Русская мысль. 1891. № 3. (REC. at: Historical review, vol. 1., Russian thought, vol. 3.)

MILYUKOV, P. N. 1918. Essays on the history of Russian culture. 7th ed. Moscow, Part 1 - 2. Publishing House M. and S. Sabashnikov.

MILYUKOV, P. N. 1993. Essays on the history of Russian culture. Vol. 1. Культура, Moscow: Progress: Culture. ISBN 5-01-004446-3

PORUBEC, D. 2018. O troch typoch fi lozofi e v kontexte európskeho myslenia. In: Theologos. vol. 20, n. 2, pp. 103-113. ISSN 1335 - 557.

RAMAZANOV, S. P. 1999. Crisis in Russian historiography of the beginning of the XX century. In 2 Hours Volgograd: publishing house Volgograd State University, Part 1. (Part 2. 2000). ISBN 5-85534-233-6.

SIDNENKO, T. I. 2006. Ideological-theoretical and methodological views of representatives of the Russian liberal-historical thought of the end of the XIX beginning of the XX centuries. Nestor. ISBN 5-303-00244-6.

SIDNENKO, T. I. 2008. Russian liberal historiography and European philosophical thought in the late XIX-early XX century. // News of the Russian state pedagogical University named after A. I. Herzen, no. 11 (72): Social and humanitarian Sciences (philosophy, history, cultural studies, linguistics, literary studies, law): Scientific journal. SPb., pp. 53 - 62. ISSN 1992-6464.

SIDNENKO, T. I. 2014. To the origins of the competence approach (liberal historians of the late XIX - early XX century, on the reform of education in Russia / / Modern problems of science and education, n. 6. Available online: http://www.scienceeducation.ru/ru/article/view? id=16343 [accessed 30.03.2020]. eISSN: 2070-7428.

SIDNENKO, T. I. 2019. Liberal-historical thought of the late XIX - early XX centuries in the context of research on the conceptual and methodological renewal of the Humanities in Russia. (Analysis of the historical development of educational practice). In: Clio, vol. 6, (150), pp. 24-30. ISSN: 2070-9773.

SIDNENKO, T. I. 2015. "Academic mobility" in the late XIX-early XX century. Liberal professorship and Higher school of social Sciences in Paris. Izvestiya Saint Petersburg state agrarian University. Quarterly scientific journal. - Special issue for the 111th anniversary of Spbgau. SPb., Ed. thief. SPb., pp. 156-159. ISSN: 20781318. SIDNENKO, T. I. 2014. To the origins of the competence approach (liberal historians of the late XIX-early XX century. on the reform of education in Russia. Modern problems of science and education, n. 6. Available online: http://www.science-education.ru/ru/article/view?id=16343 [accessed 30.03.2020]. eISSN: 2070-7428.

SAFIN, J. 2017. Paradoxes of Russian after-revolutionary development. The Jews and Euroasian movement. In: Historia Ecclesiastica, vol. 8, n. 2, pp. 105-120.

TAVILLA, I. 2017. Despair as eternal damnation of the self a biblical anthropology in outline. In: European Journal of Science and Theology, vol. 13, n. 3, pp. 163-173. ISSN 1841-0464.

VINOGRADOFF, P. 1905. The Growth of the Manor. London. by Dr. P. Vinogradoff. Swan Sonnenschein \& Co.: The Macmillan Co.

ZALEC, B. - PAVLIKOVA, M. 2019. Religious tolerance and intolerance. In: European Journal of Science and Theology, vol. 15, n. 5, pp. 39-48. ISSN 1841-0464.

Words: 5554

Characters: 36441 (20,25 standard pages)

Prof. Dr. Tatyana Sidnenko, $\mathrm{PhD}$

Faculty of Economics 
Department of State and Municipal Administration Leningrad State University named after A.S. Pushkin

Petersburg highway, 10

196605 Pushkin

Russian Federation

sidnenko@list.ru

Dr. Primož Repar

Central European Research Institute Soeren Kierkegaard Ljubljana

Ulica Lili Novy 25

SI-1000 Ljubljana

Slovenia

primoz.repar@t-2.net

Assoc. Prof. Sergey A. Polevoy

Department of Management

Financial University under the Government of the Russian Federation

49 Leningradsky prospect 125993, Moscow

Russian Federation

SAPolevoy@fa.ru

Assoc. Prof. Elena V. Shamalova, PhD

Department of Economics and Management

I.M. Sechenov First Moscow State Medical University (Sechenov University)

8 Trubetskaya Street

119991, Moscow

Russian Federation

elenavic975@yandex.ru

Prof. Nina I. Kryukova

Department of State and Legal Disciplines

Plekhanov Russian University of Economics,

36 Stremyannyi Pereulok

115093, Moscow

Russian Federation

ninari68@mail.ru 